Article

\title{
Employee Fitness Programs: Exploring Relationships between Perceived Organizational Support toward Employee Fitness and Organizational Sustainability Performance
}

\author{
Zhe Wang ${ }^{1,2}$, Chunhong Liu ${ }^{1}$, Shuai Yang ${ }^{1, *(1)}$ and Lei Li ${ }^{1}$ \\ 1 Glorious Sun School of Business and Management, Donghua University, Shanghai 200051, China; \\ zhewang1981121@126.com (Z.W.); chliu@dhu.edu.cn (C.L.); 2171052@mail.dhu.edu.cn (L.L.) \\ 2 Department of Physical Education, Donghua University, Shanghai 201620, China \\ * Correspondence: shuai.yang@dhu.edu.cn; Tel.: +86-136-1191-7568
}

Received: 2 April 2018; Accepted: 5 June 2018; Published: 8 June 2018

\begin{abstract}
This study investigates the influence of employee fitness programs on organizational sustainability performance from the perspective of organizational support as perceived by employees. Organizational sustainability performance was specified as a second-order factor, which was affected by three first-order factors: financial performance, social performance, and environmental performance. A snowball sampling method was employed to conduct an online survey of working adults in Shanghai to test the proposed hypotheses. Results show that perceived organizational support toward employee fitness has a positive and significant effect on organizational sustainability performance, and the positive effect is mediated by job satisfaction and organizational commitment. This study also provides theoretical and managerial implications.
\end{abstract}

Keywords: employee fitness programs; perceived organizational support toward employee fitness; organizational sustainability performance; job satisfaction; organizational commitment

\section{Introduction}

Today, fitness is no longer about the pursuit of a fashionable appearance; rather, its importance lies in an individual's desire to become healthy, comprising a vital part of many people's lives. According to national commercial information, the U.S. had 30,500 fitness clubs at the end of January 2012. Similarly, the fitness industry in developing countries has experienced a period of development over the past decade. For example, the number of commercial fitness clubs in China reached 5749 in 2012, a significant change from the 1434 recorded in 2004 [1].

As such, more companies have paid increasing attention to employee fitness programs, which range from providing in-house facilities for employees to providing company-paid memberships at professional fitness clubs. One underlying motivation for developing employee fitness programs was that "improved employee's health would stem rapidly rising health-care costs" [2] (p. 153). Assessment of such employee fitness programs has demonstrated several positive effects on employees' health-related and work-related outcomes. For example, employee fitness programs are associated with lower health risks and increased productivity [3].

Although it is important to study the relationships between employee fitness programs and employees' health and work performance, it is also worth examining the possible influence of employee fitness programs on an organization's overall sustainability performance through enhancing employees' perceived support toward their fitness. The assumption is that, as more individuals become dedicated to fitness, it is important to be able to exercise during the workday. Moreover, employee fitness 
programs represent organizations' concern for and support toward employee benefit programs such as health and fitness. Such organizational support, as perceived by employees, improves their organizational commitment and job satisfaction [4]. Therefore, employee fitness programs can be useful in attracting and retaining competent employees, which is important to improve organizational sustainability performance [5]. On the basis of these assumptions, we aim to examine the effect of employees' perceived organizational support toward their fitness on organizational sustainability performance as well as the mediating effect of job satisfaction and organizational commitment.

\section{Literature Review}

\subsection{Perceived Organizational Support toward Employee Fitness}

In 1986, Eisenberger and colleagues [4] first proposed the construct of perceived organizational support in their research on social psychology and organizational behavior. Since then, the construct has captured widespread attention. According to the Social Exchange Theory, relationships between organizations and employees are usually described as reciprocal interdependent relationships [6]. Reciprocal exchanges are defined by the understanding that one party depends on the other. According to Cropanzano and Mitchell [7], the process of reciprocal exchanges begins when one party (usually the organization) makes a move; then, the other party (employees) reciprocates. Employees rely on organizations to achieve their objectives, and organizations depend on employees to carry out their work processes and attain their goals.

Perceived organizational support represents an employee's concerns in terms of how much the organization cares about his/her well-being [4]. According to this model, when employees perceive support from the organization, they repay their organization. As part of this repayment process, employees become emotionally attached to the organization and are increasingly dedicated to help the organization achieve its goals. That is, employees' perceived support from their organization encourages them to increase affective attachment and pro-social acts on behalf of the organization $[4,8]$.

We define perceived organizational support toward employee fitness in the following way: employees' specific concerns about how much an organization cares about their fitness and overall well-being. The construct shares some characteristics of perceived organizational support. Specifically, if employees feel that an organization cares about their fitness through a variety of policies to reward their work, their social-emotional needs can be met from such organizational support, leading to a willingness to work harder to make contributions to the organization.

Extant studies on employee fitness programs have indicated the positive effects of employee fitness programs on different types of firm performance, such as work performance [9-17], productivity [13,14,18-23], sales [23,24], mental performance [25-28], absenteeism [18,21,22,29-33], as well as social performance [34]. However, studies on employee fitness programs have mostly focused on the financial performance of an organization; they largely have not considered the effects of employee fitness programs on social and environmental perspectives of organizational sustainability performance with one exception [34]. Thus, we aim to explore the effect of employee fitness programs on organizational sustainability performance from the perspective of employees' perceived organizational support.

\subsection{Perceived Organizational Support toward Employee Fitness and Organizational Sustainability Performance}

Many organizations are under pressure to adopt strategies and activities to meet their financial needs while sustaining the social and environmental resources that are needed in the future [35]. Organizational sustainability performance measures the degree to which an organization integrates environmental, social, and economic prosperity into their operations [36]. This can similarly be viewed as a process whereby organizations achieve their long-term performance of goals, including financial, social, and environmental performance [37]. 
The first dimension of organizational sustainability performance is financial performance, which comprises an organization's general financial health within a given period [38]. The second dimension of organizational sustainability performance is social performance. Chen and Delmas [39] define social performance as an organization's responsibilities to its stakeholders (e.g., employees, shareholders, etc.). The third dimension is environmental performance, which represents an organization's overall behavior toward the natural environment [40].

The social exchange theory indicates that, in reciprocal interdependent relationships, one party's voluntary behavior is motivated by the other party's expected returns [6]. As evidenced by the norm of reciprocity, in the reciprocal interdependent relationships between organizations and employees [6], employees rely on the organization to achieve their objectives and, conversely, an organization depends on its employees to improve its overall performance. Thus, employees who have perceived a high level of support from an organization are willing to repay said organization with increased efforts [4].

Perceived organizational support toward employee fitness can be viewed as an assurance that an organization will offer assistance with work, acting as an incentive for an employee's work performance. Employees who perceive an organization supports their fitness might feel an emotional connection with the organization and, consequently, may be more dedicated to their job [41]. As a result, employees will work hard to support their organization towards accomplishing both organizational standards and goals, ultimately increasing organizational sustainability performance (see the theoretical framework in Figure 1). Specifically, perceived organizational support can provide organizations with financial benefits, such as improving work performance [42]. Byrne and Hochwarter [43] have argued that perceived organizational support may facilitate social responsibility by reducing stressors and encouraging commitment, which measures organizational social performance. Furthermore, perceived organizational support leads to improvements in organizational internal processes, which are associated with organizational environmental performance [44]. On the contrary, if employees perceive that organizations are unsupportive, they might be dissatisfied with their job [45] and carry out tasks ineffectively [42]. Such a lack of organizational support can result in low organizational sustainability performance. Thus, we propose that:

H1. Perceived organizational support toward employee fitness is positively associated with perceived organizational sustainability performance.

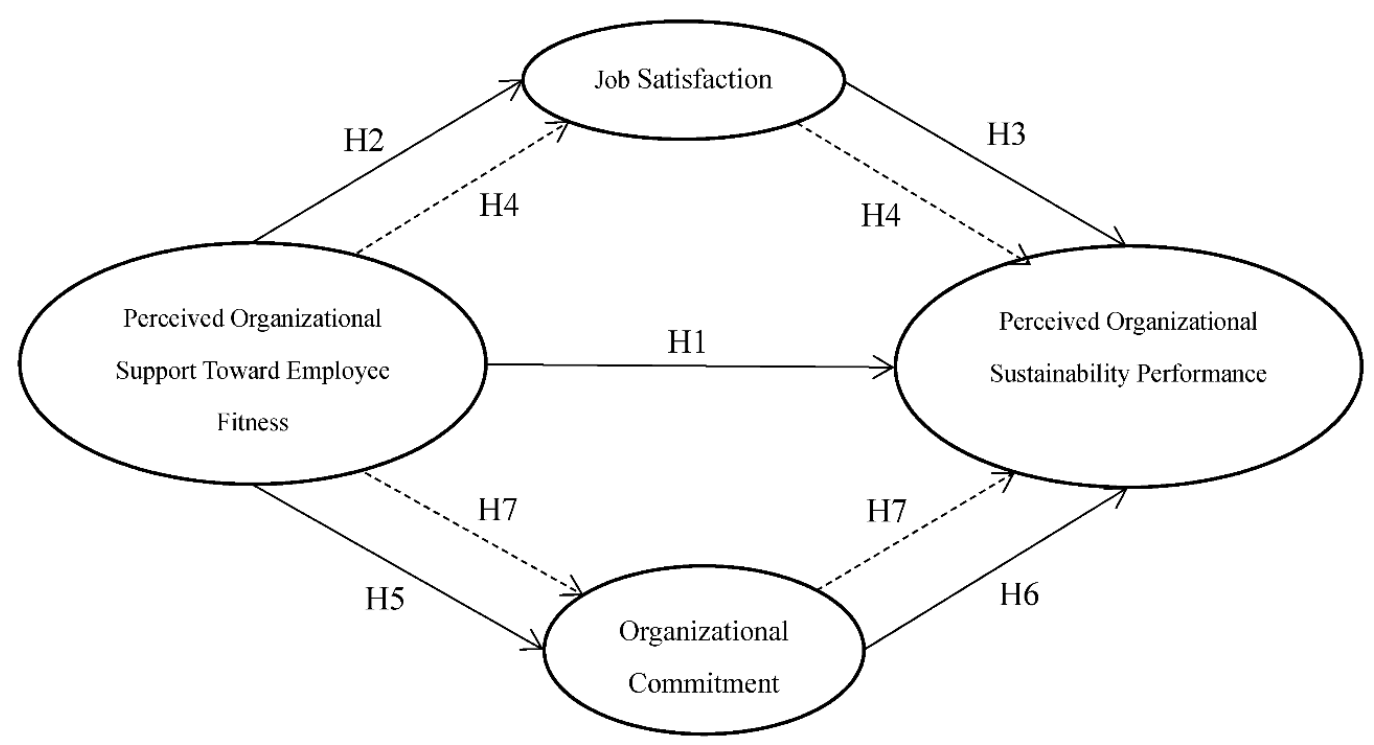

Figure 1. Conceptual model. Note: $\rightarrow$ Direct effects; - - > Indirect effects. 


\subsection{The Mediator: Job Satisfaction}

Vroom [46] defines job satisfaction as an employee's positive orientation to his or her current job role. Price [47] proposes that job satisfaction is a sentimental orientation, which is caused by one's role in the system. If an employee has a positive sentimental orientation, he or she will feel satisfied; otherwise, he or she will not be satisfied. Porter and Lawler [48] pointed out that an employee's job satisfaction depends on the gap between what employees think they should receive from their employer and what they actually receive. Thus, employees who perceive a smaller gap between their remuneration and the actual reward would have a higher degree of job satisfaction. Similarly, Robbins [49] defines job satisfaction as an employee's overall attitude towards work, pointing out that job satisfaction depends on the difference between the compensation that employees believe they should receive from the job and the actual compensation they receive.

Prior literature has indicated that perceived organizational support can meet employees' socio-emotional needs and increase their performance-reward expectancies, contributing to overall job satisfaction [42]. For example, Burke [50] investigated nurses engaged in medical work and found that perceived organizational support was crucial in affecting job satisfaction among nurses. Harris and colleagues [51] conducted a study on 418 selected research subjects and found that perceived organizational support increased employee job satisfaction.

In return, job satisfaction is central to improving organizational sustainability performance [52]. Past research has indicated the positive influence of job satisfaction on organizational sustainability performance. For example, Brooks [53] has suggested that an employee who is satisfied with his or her job would not leave an organization. As a result, organizations with a low turnover rate have larger profits. This explains why employees improve the bottom line of organizations' sustainability performance. Choo and Bowley [54] also found that employee satisfaction and organizational performance are interrelated. As a result of the theoretical similarity between perceived organizational support toward employee fitness and perceived organizational support, the same effects are expected. Hence, we hypothesize:

H2. Perceived organizational support toward employee fitness is positively associated with job satisfaction.

H3. Job satisfaction is positively associated with perceived organizational sustainability performance.

H4. Job satisfaction mediates the influence of perceived organizational support toward employee fitness on perceived organizational sustainability performance.

\subsection{The Mediator: Organizational Commitment}

Researchers have defined organizational commitment in a variety of ways [55]. For example, Bartlett [56] defines organizational commitment as an employee's attachment toward his or her organization. Meyer and Allen [57] define an employee's organizational commitment as his or her dedication and loyalty to their organization.

Meyer and Allen [58] propose three dimensions of organizational commitment. The first dimension is affective commitment, which is defined as "an employee sentimental attachment, sense of belonging and participation in the organization" [58]. Employees stay with an organization because they believe in and recognize themselves with the organization. Affective commitment captures employees' degree of attachment to their organizations [59]. The second dimension is continuance commitment, which is an employee's perceived expense for leaving his or her organization [58], which is "a consciousness of the expenditure linked with parting the organization" [60]. The third is normative commitment, a type of moral commitment. It is defined as an employee's feelings of obligation to stay with his or her organization $[58,59]$. Therefore, employees remain with organizations, as they feel grateful to maintain employment.

Using reciprocity norms and the social exchange theory, Eisenberger and colleagues [4] proposed that the key to organizational commitment is an employee's perceived support from his or her 
organization. Once employees feel support from an organization, they will perceive a sense of obligation. Similarly, Eisenberger et al. [61] and Rhoades and Eisenberger [62] found that when employees perceive support from an organization, they will increase their organizational commitment and, at the same time, decrease their turnover intention, rewarding the organization with more innovative solutions and work execution force. Thus, we argue that perceived organizational support toward employee fitness increases organizational commitment.

In addition, strong organizational commitment is required to capture new business opportunities and generally exert positive effects on organizational sustainability performance [63]. Using commitment theories, organizational commitment leads to organizational growth [64] and organizational sustainability [65]. Thus, strong organizational commitment can create a conductive environment and reinforces sustainable values in the workplace, which leads to the implementation of sustained practices in an organization [66]. Therefore, we predict the following hypotheses:

H5. Perceived organizational support toward employee fitness is positively associated with organizational commitment.

H6. Organizational commitment is positively associated with perceived organizational sustainability performance.

H7. Organizational commitment mediates the influence of perceived organizational support toward employee fitness on perceived organizational sustainability performance.

\section{Methods}

\subsection{Participants and Procedures}

The original questionnaires were developed in English. Before administering this study, to ensure that the questions were translated properly, we first translated the survey into Chinese and then back-translated it into English $[67,68]$. We employed a snowball sampling method to conduct an online survey of working adults to test the proposed hypotheses. Specifically, we first sent out invitations through WeChat messages to faculties at a university in Shanghai to recruit first-round participants. We then encouraged them to forward the online survey to their friends and relatives through WeChat to obtain more participants.

From the invitations, this study distributed 320 questionnaires and received 276 valid responses. The response rate was $86.25 \%$. Table 1 displays the descriptive statistics of the 276 usable responses. A majority of the survey participants were male (52.17\%), aged 25-34 (55.80\%), single (49.28\%), and had a bachelor's degree $(40.94 \%)$. One hundred and five participants $(38.04 \%)$ reported tenure in their companies of $2-5$ years and $38.77 \%$ of the participants reported having a non-management role.

Table 1. Descriptive statistics of sample characteristics $(n=276)$.

\begin{tabular}{cccc}
\hline Characteristics & Categories & $N$ & \% \\
\hline \multirow{2}{*}{ Gender } & Male & 144 & 52.17 \\
& Female & 132 & 47.83 \\
\hline \multirow{3}{*}{ Age } & $18-24$ & 66 & 23.91 \\
& $25-34$ & 154 & 55.8 \\
& $35-44$ & 41 & 14.86 \\
& $45-54$ & 11 & 3.99 \\
Marital status & 55 or older & 4 & 1.45 \\
& Single & 136 & 49.28 \\
& Married & 131 & 47.46 \\
& Divorced/Widowed & 9 & 3.26 \\
\hline \multirow{2}{*}{ Education } & High school or below & 64 & 23.19 \\
& Diploma & 74 & 26.81 \\
& Bachelor & 113 & 40.94 \\
& Masters/Doctoral & 25 & 9.06 \\
\hline
\end{tabular}


Table 1. Cont.

\begin{tabular}{cccc}
\hline Characteristics & Categories & $N$ & $\%$ \\
\hline \multirow{4}{*}{ Organizational tenure } & One year or less & 24 & 8.7 \\
& $2-5$ years & 105 & 38.04 \\
& $6-10$ years & 96 & 34.78 \\
& $11-15$ years & 29 & 10.51 \\
& 16 years or more & 22 & 7.96 \\
\hline \multirow{3}{*}{ Managerial level } & Non-management & 107 & 38.77 \\
& Lower & 63 & 22.83 \\
& Middle & 74 & 26.81 \\
& Upper & 32 & 11.59 \\
\hline \multirow{3}{*}{ Nature of organization } & State-owned & 63 & 22.83 \\
& Foreign-funded & 165 & 59.78 \\
& Private & 48 & 17.39 \\
\hline
\end{tabular}

\subsection{Measures}

To assess perceived organizational support toward employee fitness, we borrowed and modified the five-item perceived organizational support toward the environment (POS-E) scale developed by Lamm, Tosti-Kharas, and King [68]. The sample items included "I feel that I am able to keep fit as I want to at the company where I currently work," "My company cares about whether I can keep fit", and "My company provides an incentive for me to keep me fit". All items, unless otherwise noted, were rated on seven-point Likert scales. Coefficient alpha was 0.95.

To measure job satisfaction, we employed the scale developed by Cammann et al. [69]. The sample items included "All in all, I am satisfied with my job", and "In general, I don't like my job". Coefficient alpha was 0.90 .

To measure organizational commitment, we used the three-dimensional, 12-item scale developed by Pan et al. [70]. It included three dimensions: affective, continuance, and normative commitment. The sample items of affective commitment included "Problems faced by my company are likely to my problems" and "I feel a strong sense of belongingness toward my company". The sample items of continuance commitment included "If I do not support my company, I may never be able to find a company to support" and "To me, the cost of not supporting my company is far higher than the benefits". The sample items of normative commitment included "I feel obligated to continue supporting my company" and "Even if there is a better company to choose, I will still support my company". Coefficient alphas of the three dimensions were $0.94,0.89$, and 0.92 , respectively.

To measure perceived organizational sustainability performance, we used the three-dimensional, eight-item scale developed by Lee and Ha-Brookshire [38]. The items of financial social performance included "I am aware that my company has competitive advantages in its sales and profit growth", "I am aware that our company has a competitive advantage in cost saving and efficiency", and "I am aware that our company has a competitive advantage in its brand value". The items of social performance included "I am aware that my company has a policy to strive to be a good corporate citizen" and "I am aware that my company has a policy to respect business ethics". The items of environmental performance included "I am aware that my company has an initiative to reduce, reuse, and recycle", "I am aware that my company has an initiative to reduce the negative environmental impact of its products", and "My company has a policy to improve its energy efficiency". Coefficient alphas of financial performance, social performance, and environmental performance were $0.90,0.91$, and 0.92 , respectively.

\section{Analyses and Results}

Table 2 displays the descriptive statistics of the constructs in the study. Before the hypotheses testing, we assessed their reliability and validity. 
Table 2. Mean, standard deviations, factor loading, CR, and AVE.

\begin{tabular}{|c|c|c|c|c|c|}
\hline Constructs & Mean & $\begin{array}{c}\text { Standard } \\
\text { Deviations }\end{array}$ & $\begin{array}{l}\text { Factor } \\
\text { Loading }\end{array}$ & CR & AVE \\
\hline $\begin{array}{l}\text { Perceived Organizational Support } \\
\text { toward Employee Fitness }\end{array}$ & 4.59 & 1.24 & & 0.96 & 0.83 \\
\hline POS1 & & & 0.92 & & \\
\hline POS2 & & & 0.91 & & \\
\hline POS3 & & & 0.91 & & \\
\hline POS5 & & & 0.90 & & \\
\hline POS1 & & & 0.92 & & \\
\hline Job Satisfaction & 4.30 & 1.17 & & 0.94 & 0.83 \\
\hline JS1 & & & 0.89 & & \\
\hline JS2 & & & 0.93 & & \\
\hline JS3 & & & 0.91 & & \\
\hline Organizational Commitment & 4.29 & 0.83 & & 0.97 & 0.79 \\
\hline Affective Commitment & 4.67 & 1.02 & & 0.95 & 0.80 \\
\hline $\mathrm{AC} 1$ & & & 0.91 & & \\
\hline AC2 & & & 0.91 & & \\
\hline AC3 & & & 0.89 & & \\
\hline AC4 & & & 0.90 & & \\
\hline AC5 & & & 0.86 & & \\
\hline Continuance Commitment & 4.06 & 1.01 & & 0.92 & 0.74 \\
\hline $\mathrm{CC} 1$ & & & 0.92 & & \\
\hline $\mathrm{CC} 2$ & & & 0.86 & & \\
\hline $\mathrm{CC} 3$ & & & 0.94 & & \\
\hline $\mathrm{CC} 4$ & & & 0.71 & & \\
\hline Normative Commitment & 3.94 & 1.08 & & 0.95 & 0.87 \\
\hline $\mathrm{NC} 1$ & & & 0.93 & & \\
\hline NC2 & & & 0.94 & & \\
\hline NC3 & & & 0.92 & & \\
\hline $\begin{array}{l}\text { Perceived Organizational } \\
\text { Sustainability Performance }\end{array}$ & 4.42 & 0.98 & & 0.98 & 0.86 \\
\hline Financial Performance & 4.48 & 1.08 & & 0.94 & 0.83 \\
\hline FP1 & & & 0.93 & & \\
\hline FP2 & & & 0.92 & & \\
\hline FP3 & & & 0.88 & & \\
\hline Social Performance & 4.33 & 1.33 & & 0.96 & 0.92 \\
\hline SP1 & & & 0.96 & & \\
\hline SP2 & & & 0.96 & & \\
\hline Environmental Performance & 4.43 & 1.21 & & 0.95 & 0.87 \\
\hline EP1 & & & 0.93 & & \\
\hline EP2 & & & 0.94 & & \\
\hline EP3 & & & 0.92 & & \\
\hline
\end{tabular}

Note: CR represents composite reliability and AVE represents average variance extracted.

\subsection{Reliability and Validity Analysis}

A confirmatory factor analysis (CFA) was used to access the discriminant validity. For all constructs, the factor loadings were larger than 0.70 and the composition reliability (CR) was higher than 0.90 . Additionally, the average variances extracted (AVE) was higher than 0.70 . Thus, the scales had acceptable reliability and convergent validity. Further, we compared each construct's AVE estimates with its correlation matrix in Table 3 . The results showed that all constructs in this study had accepted discriminant validity $[71,72]$. 
Table 3. Discriminant validity.

\begin{tabular}{lcccccccc}
\hline Mean & $\mathbf{1}$ & $\mathbf{2}$ & $\mathbf{3}$ & $\mathbf{4}$ & $\mathbf{5}$ & $\mathbf{6}$ & $\mathbf{7}$ & $\mathbf{8}$ \\
\hline 1. POSEF & 0.83 & & & & & & & \\
2. JS & $0.68^{* * *}$ & 0.83 & & & & & & \\
3. AC & $0.59^{* * *}$ & $0.56^{* * *}$ & 0.80 & & & & & \\
4. CC & $0.33^{* * *}$ & $0.18^{* * *}$ & $0.47^{* * *}$ & 0.74 & & & & \\
5. NC & $0.64^{* * *}$ & $0.62^{* * *}$ & $0.57^{* * *}$ & $0.26^{* * *}$ & 0.87 & & & \\
6. FP & $0.67^{* * *}$ & $0.67^{* * *}$ & $0.77^{* * *}$ & $0.34^{* * *}$ & $0.61^{* * *}$ & 0.83 & & \\
7. SP & $0.35^{* * *}$ & $0.39^{* * *}$ & $0.38^{* * *}$ & $0.02^{* * *}$ & $0.35^{* * *}$ & $0.41^{* * *}$ & 0.92 & $0.41^{* * *}$ \\
8. EP & $0.74^{* * *}$ & $0.67^{* * *}$ & $0.65^{* * *}$ & $0.25^{* * *}$ & $0.59^{* * *}$ & $0.65^{* * *}$ & 0.87 \\
\hline
\end{tabular}

Note: POSEF = Perceived Organizational Support toward Employee Fitness; JS = Job Satisfaction; AC = Affective Commitment; $\mathrm{CC}=$ Continuance Commitment; $\mathrm{NC}=$ Normative Commitment; FP $=$ Financial Performance; $\mathrm{SF}=$ Social Performance; EF = Environmental Performance; The diagonal values are the AVE, and the other elements are the correlation estimates; ${ }^{* * *} p<0.001$.

\subsection{Test of $H 1$}

To test Hypothesis 1, we conducted structural equation models to examine whether perceived organizational support toward employee fitness was positively associated with perceived organizational sustainability performance. The model shows accepted model fit $\left(\chi^{2} / \mathrm{df}=1.98\right.$, Comparative Fit Index (CFI) $=0.96$, Non-normed Fit Index (NNFI) $=0.96$, Goodness of Fit Index $(\mathrm{GFI})=0.89$, and Root Mean Square Error of Approximation $($ RMSEA $)=0.06)$. Figure 2 shows that perceived organizational support toward employee fitness had a significantly positive direct effect on perceived organizational sustainability performance $(b=0.89, p<0.001)$. Thus, H1 was supported.

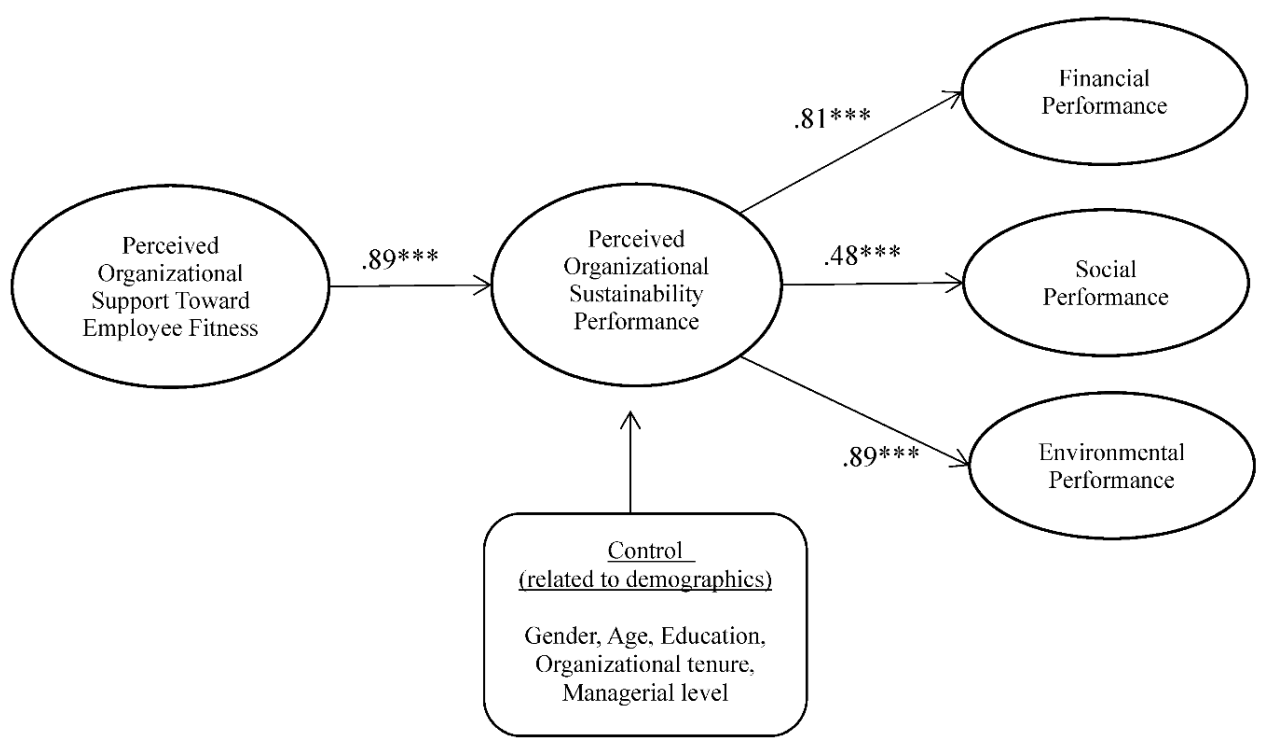

Figure 2. The influence of perceived organizational support toward employee fitness on perceived organizational sustainability performance. Note: ${ }^{* *} p<0.001$.

\subsection{Test of $\mathrm{H} 2$ and $\mathrm{H} 3$}

Figure 3 shows the mediating model of job satisfaction. The model shows accepted model fit $\left(\chi^{2} / \mathrm{df}=1.73, \mathrm{CFI}=0.97, \mathrm{NNFI}=0.97, \mathrm{GFI}=0.91\right.$, and RMSEA $\left.=0.05\right)$. The structural equation modeling (SEM) results show that perceived organizational support toward employee fitness had a significantly positive direct effect on job satisfaction $(b=0.74, p<0.001)$ and job satisfaction had a significantly positive direct effect on perceived organizational sustainability performance $(b=0.43$, $p<0.001)$. Hence, $\mathrm{H} 2$ and $\mathrm{H} 3$ were supported. 


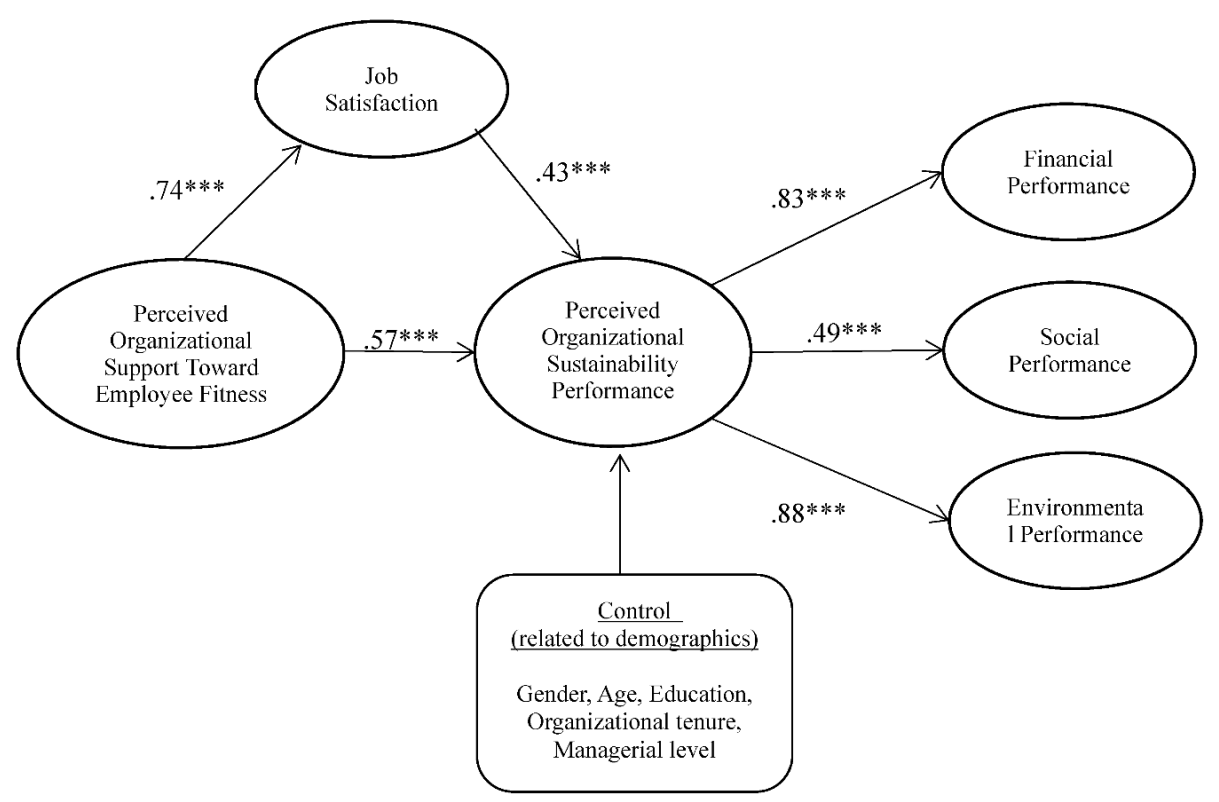

Figure 3. The mediating model of job satisfaction. Note: ${ }^{* *} p<0.001$.

\subsection{Test of $\mathrm{H} 5$ and $\mathrm{H} 6$}

We also investigated the mediating model of organizational commitment (see Figure 4). The model shows accepted model fit $\left(\chi^{2} / \mathrm{df}=2.29, \mathrm{CFI}=0.93, \mathrm{NNFI}=0.93, \mathrm{GFI}=0.85\right.$, and $\left.\mathrm{RMSEA}=0.07\right)$. The results show that perceived organizational support toward employee fitness had a significantly positive direct effect on organizational commitment $(b=0.78, p<0.001)$ and organizational commitment had a significantly positive direct effect on perceived organizational sustainability performance $(\mathrm{b}=0.87, p<0.001)$. Hence, H5 and H6 were supported.

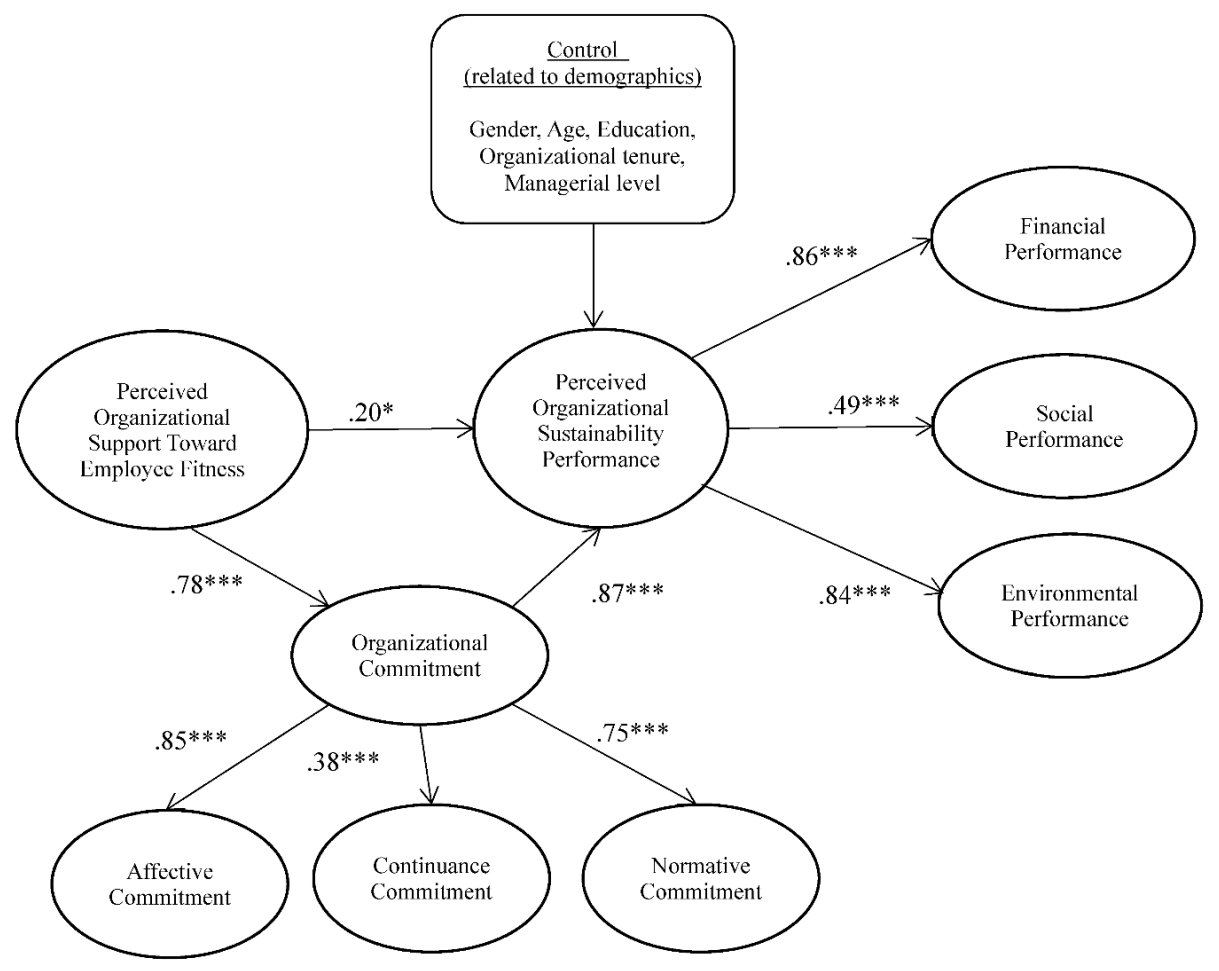

Figure 4. The mediating model of organizational commitment. Note: ${ }^{*} p<0.05 ;{ }^{* * *} p<0.001$. 


\subsection{Test of $\mathrm{H} 4$ and $\mathrm{H7}$}

Figure 2 shows that perceived organizational support toward employee fitness had a significantly positive direct effect on perceived organizational sustainability performance $(b=0.89, p<0.001)$. When we included "job satisfaction" in the model, perceived organizational support toward employee fitness continued to have a positive but weak direct effect of 0.57 on perceived organizational sustainability performance (Figure 3). Thus, perceived organizational support toward employee fitness indirectly affected perceived organizational sustainability performance through job satisfaction where the indirect effect was $0.32(0.74 \times 0.43)$. Therefore, job satisfaction partially mediated the positive effect of perceived organizational support toward employee fitness on perceived organizational sustainability performance. Thus, $\mathrm{H} 4$ was supported.

When we included "organizational commitment" in the model, perceived organizational support toward employee fitness continued to have a positive but weak direct effect of 0.20 on perceived organizational sustainability performance (Figure 4). Thus, organizational commitment partially mediated the positive influence of perceived organizational support toward employee fitness on perceived organizational sustainability performance, where the indirect effect was $0.68(0.78 \times 0.87)$. Thus, H7 was supported.

Finally, we included both mediators in the model (see Figure 5). The model shows accepted model fit $\left(\chi^{2} / \mathrm{df}=2.18, \mathrm{CFI}=0.93, \mathrm{NNFI}=0.93, \mathrm{GFI}=0.84\right.$, and RMSEA $\left.=0.07\right)$. The influence of perceived organizational support toward employee fitness on perceived organizational sustainability performance was not significant $(b=0.08, p=0.39)$. This suggests that the influence of perceived organizational support toward employee fitness on perceived organizational sustainability performance was fully mediated by organizational commitment and job satisfaction, which further supports $\mathrm{H} 4$ and $\mathrm{H} 7$.

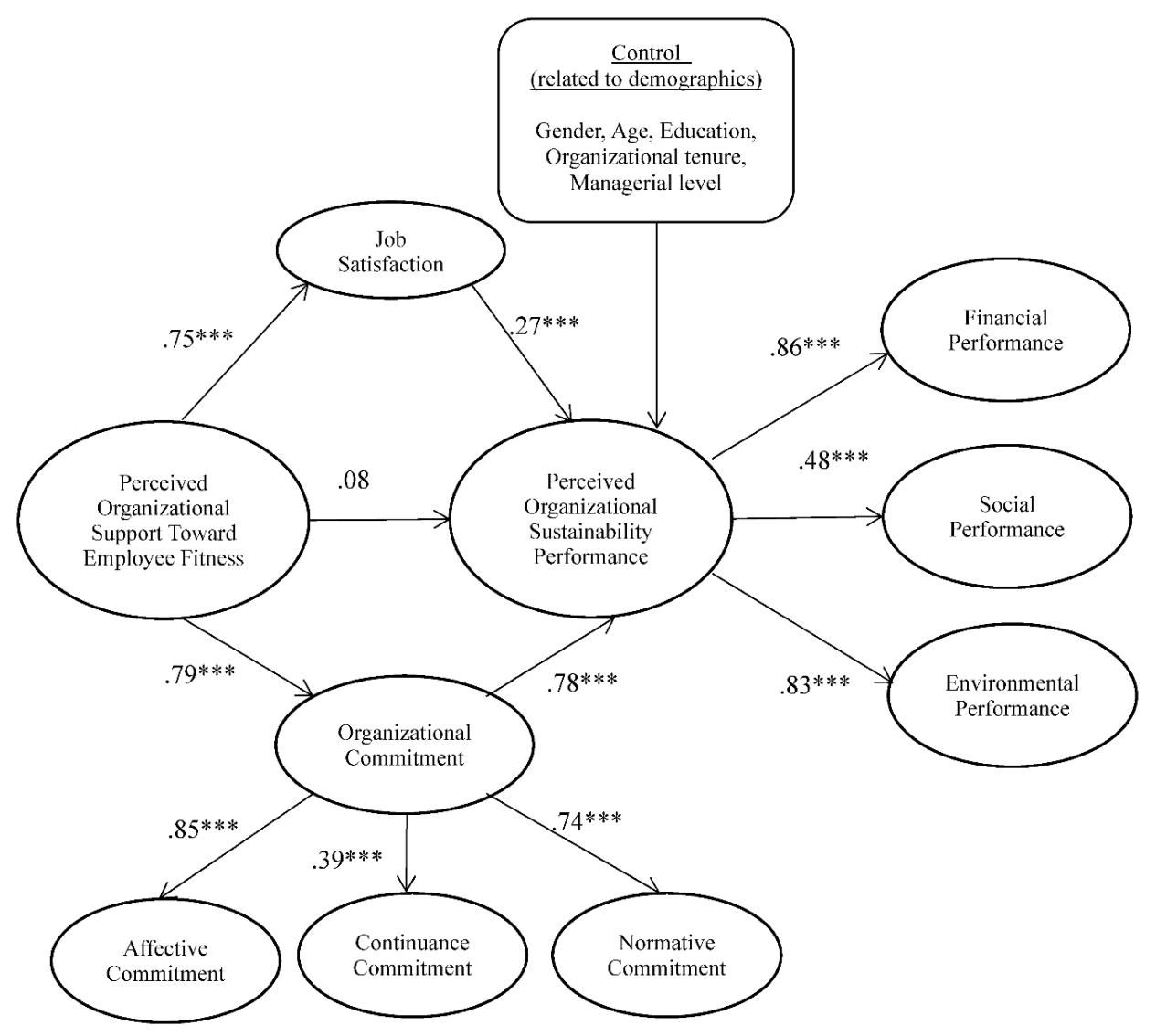

Figure 5. The mediating model of organizational commitment and job satisfaction. Note: ${ }^{* * *} p<0.001$. 


\section{Conclusions, Implications, and Limitations}

\subsection{Conclusions and Discussion}

First, the main purpose of the research was to examine the influence of perceived organizational support toward employee fitness on organizational sustainability performance. The results show that perceived organizational support toward employee fitness exerted a significantly positive effect on organizational sustainability performance. Organizational sustainability performance was specified as a second-order factor, which was affected by three first-order factors, including financial, social, and environmental performance. All three types of performance had crucial implications for organizational sustainability performance. However, as can be seen from our results, the relative importance of the three types of performance was quite different. Specifically, social performance was found to be the least important dimension of organizational sustainability performance. The results are comparable to those in previous studies, which demonstrate that social performance is a "soft" indicator of organizational performance [39]. For example, some studies have suggested that social performance is less influential than environmental performance [73,74].

Second, job satisfaction mediated the positive influence between perceived organizational support toward employee fitness and organizational sustainability performance. In other words, when employees perceived greater organizational support toward their fitness through employee fitness programs, they had higher job satisfaction. In return, when employees felt satisfied with their jobs, organizational sustainability performance was likely to increase.

Third, organizational commitment mediated the positive influence between perceived organizational support toward employee fitness and organizational sustainability performance. That is, the greater perceived organizational support toward employee fitness, the more committed employees were to their organization. Thus, when employees were dedicated to their organization, organizational sustainability performance was affected.

Organizational commitment takes three distinct forms. Our findings show that affective commitment is the most important dimension and continuance commitment is the least influential dimension. The results are consistent with previous studies [75,76]. In comparison to financial and normative commitment, continuance commitment is a negative type of organizational commitment [76] which measures how employees are forced into relationships with the organizations [77]. Hence, it is reasonable to find that continuance commitment was the least influential dimension of organizational commitment.

Additionally, participants in our study came from different types of organizations, including state-owned, foreign-funded, and private organizations. Examining the nature of organizations as a moderator in the model might provide an interesting way to look at the variables of interest in this study. Thus, we estimated the moderating effect of the nature of organizations. We divided the whole sample into state-owned $(N=63)$, foreign-funded $(N=165)$, and private organization $(N=48)$ groups and conducted a multiple group analysis to estimate the difference among the three groups. If the variation of the $x^{2}$ statistic of the constraint model and the unconstraint model was more than 3.84, there was a significant difference between the two models. The results in Table 4 show that only the effect of job satisfaction and organizational sustainable performance in the foreign-funded organization group was significantly stronger than the effect for the state-owned organization group $(p<0.05)$. There were no significant differences among the three groups on the other path coefficients. It is notable that, although the path coefficients from commitment to organizational sustainable performance and from commitment to continuance commitment were not significant for the private organization group, the multiple group analysis results show that they were not significantly weaker than those in the other two groups ( $p s>0.05)$. 
Table 4. The moderating effect of the nature of organization.

\begin{tabular}{|c|c|c|c|c|}
\hline & $\begin{array}{l}\text { State-Owned } \\
\quad(N=63)\end{array}$ & $\begin{array}{l}\text { Foreign-Funded } \\
\qquad(N=165)\end{array}$ & $\begin{array}{l}\text { Private } \\
(N=48)\end{array}$ & Difference btw Groups \\
\hline POSEF-COM & $0.695^{* * *}$ & $0.825^{* * *}$ & $0.814^{* * *}$ & NS \\
\hline POSEF-JS & $0.779 * * *$ & $0.749^{* * *}$ & $0.696^{* * *}$ & NS \\
\hline POSEF-PER & 0.271 & 0.075 & 0.016 & NS \\
\hline JS-PER & 0.041 & $0.362^{* * *}$ & 0.457 * & $\begin{array}{l}\text { Significant difference between } \\
\text { state-owned and foreign-funded }\end{array}$ \\
\hline COM-PER & $0.776^{* * *}$ & $0.732 * * *$ & 0.620 & NS \\
\hline COM-AC & $0.862^{* * *}$ & $0.852 * * *$ & $0.812 * * *$ & NS \\
\hline COM-CC & $0.443^{* * *}$ & $0.483^{* * *}$ & 0.072 & NS \\
\hline COM-NC & $0.731^{* * *}$ & $0.754^{* * *}$ & $0.687^{* * *}$ & NS \\
\hline PER-FP & $0.894^{* * *}$ & $0.864^{* * *}$ & $0.757^{* * *}$ & NS \\
\hline PER-SP & $0.523^{* * *}$ & $0.446^{* * *}$ & $0.408^{* * *}$ & NS \\
\hline PER-EP & $0.852 * * *$ & $0.818^{* * *}$ & $0.807^{* * * *}$ & NS \\
\hline
\end{tabular}

Note: POSEF = Perceived Organizational Support toward Employee Fitness; COM = Commitment; JS = Job Satisfaction; $\mathrm{PER}=$ Organizational Sustainable Performance; $\mathrm{AC}=$ Affective Commitment; $\mathrm{CC}=$ Continuance Commitment; $\mathrm{NC}=$ Normative Commitment; $\mathrm{FP}=$ Financial Performance; $\mathrm{SF}=$ Social Performance; $\mathrm{EF}=$ Environmental Performance; NS $=$ No Significant Difference; ${ }^{*} p<0.05,{ }^{* * *} p<0.001$.

\subsection{Implications}

The study makes several theoretical contributions. First, we have contributed to the literature related to employee fitness programs. Although numerous studies have investigated the influence of employee fitness programs on firm performance, the majority have focused on an organization's financial performance, such as work performance [9-17], productivity [13,14,18-23], or sales [23,24]. Therefore, the current study, to the best of our knowledge, is the first to investigate the effect of employee fitness programs on an organization's overall sustainability performance. From the perspective of organizational support, this study finds that organizations experience benefits (i.e., improving organizational sustainability performance) when supporting employee fitness programs.

Second, the effects of perceived organizational support have been investigated in a variety of contexts, such as electronics and appliance salesmen [62,78], state agency employees [79], brokerage firm clerks [61], mail-processing clerks [62] and coaches in colleges and universities [80]. This study has extended current research on perceived organizational support by introducing a novel contextual construct, perceived organizational support toward employee fitness, which relates to employee fitness programs.

Third, this study discovered the psychological mechanism of perceived organizational support toward employee fitness on sustainability performance. Specifically, we found that organizational commitment and job satisfaction fully mediate the effect of perceived organizational support toward employee fitness on organizational sustainability performance. Although other research has examined the influences of organizational commitment and job satisfaction on perceived organizational support in general, this current study's findings indicate that job satisfaction and organizational commitment also are related to perceived organizational support toward employee fitness.

This study also provides some managerial implications. As more companies begin to develop employee fitness programs, our findings show that employees who feel organizational support from their organization's employee fitness programs are more satisfied with their jobs and committed to their organization. As a result, organizational sustainability performance is likely to increase. Thus, our findings support the instituting and maintaining of employee fitness programs. Practically, companies could utilize equipped in-house facilities, which should be fully staffed and have well-developed programming [81]. For those companies that cannot launch in-house programs, they can turn to outside sources, such as professional fitness clubs. Also, the personal physical test could be a major element of employee fitness programs that educate employees as to the importance 
of program commitment [81]. Notably, although employee fitness programs require an investment, they are beneficial to the organization's financial performance, such as increasing employees' physical work capacity, reducing absenteeism, and decreasing labor turnover. In fact, Clutterbuck [82] has shown that an employee fitness program of an organization with 1400 employees could save the organization $\$ 200,000$ each year in salary costs.

Second, because organizations benefit from perceived organizational support toward employee fitness, they should consider how to enhance employees' perception about their organization's support for their fitness and health development, perhaps through open communication. Studies have demonstrated the importance of open communications to employees' perceived organizational support [83]. Thus, open communications between employees and managers could be a key HR policy to improve employees' perception that organizations care about them. For example, managers could encourage employees to proactively provide feedback on the effect of employee fitness programs to signal organizational support for their employees. Managers could also encourage employees to discuss how to strengthen employee fitness levels.

\subsection{Limitations and Further Research Directions}

Our research had several limitations. First, we used a snowball sampling method to collect data. Although this method is often used in related research and has been widely accepted by academics, the method can be subject to certain biases. One concern is that participants might have forwarded the questionnaire to friends and relatives who have similar beliefs about fitness.

Second, the collected data in this research were taken at a single point in time. Future research could collect experimental or longitudinal data to investigate the precise relationships between the variables. Additionally, all variables were self-reported and measured by employees' responses in the survey. Future studies could use industrial data to examine whether the results are still valid.

Moreover, this research has found that perceived organizational support toward employee fitness could increase organizational sustainability performance. It has been noted that exercise in the workplace might distract employees away from their job responsibilities and thus decrease their work performance. We could examine the boundary conditions of the effect of perceived organizational support toward employee fitness in future studies. Lastly, perceived organizational support toward employee fitness could be related to other variables that have not been investigated in this study. Thus, we could test additional related variables to further develop this construct.

Author Contributions: Z.W. led the study and collected the data. C.L. revised the draft manuscript and provided advice to improve the manuscript. L.L. analyzed the data. S.Y. wrote the first draft manuscript and took charge of publication correspondence.

Acknowledgments: We acknowledge the financial supports from the National Science Foundation in China (No. 71602026), the Fundamental Research Funds for the Central Universities in China (No. 413000018 from Wuhan University), and Innovation Program of Shanghai Municipal Education Commission (2017-01-07-00-03-E00044).

Conflicts of Interest: The authors declare no conflict of interest.

\section{References}

1. Han, G. Construction and verification of coaches work performance model in China fitness clubs. Shandong Sports Sci. Technol. 2014, 36, 30-33.

2. Prien, K.O.; Prien, E.P. A prescribed employee fitness program and job-related attitudes. Psychol. Rep. 2003, 93, 153-159. [CrossRef] [PubMed]

3. Howard, J.; Mikalachki, A. Fitness and employee productivity. Can. J. Appl. Sport Sci. 1979, 4, $191-198$. [PubMed]

4. Eisenberger, S.; Huntington, R.; Hutchison, S.; Sowa, D. Perceived organizational support. J. Appl. Psychol. 1986, 71, 500-507. [CrossRef]

5. Shaw, J.D.; Gupta, N.; Delery, J.E. Alternative conceptualizations of the relationship between voluntary turnover and organizational performance. Acad. Manag. J. 2005, 48, 50-68. [CrossRef] 
6. Blau, P. Exchange and Power in the Social Life; Wiley: New York, NY, USA, 1964.

7. Cropanzano, R.S.; Mitchell, L. Social exchange theory: An interdisciplinary review. J. Manag. 2005, 31, 874-900. [CrossRef]

8. Levinson, H. Reciprocation: The relationship between men and organization. Adm. Sci. Quart. 1965, 9, 370-390. [CrossRef]

9. Avner, B.N.; Hamann, D.J.; Koepp, G.; Manohar, C.U.; Levine, J. Treadmill workstations: The effects of walking while working on physical activity and work performance. PLoS ONE 2014, 9, e88620.

10. Barr-Anderson, D.J.; AuYoung, M.; Whitt-Glover, M.C.; Glenn, B.A.; Yancey, A.K. Integration of short bouts of physical activity into organizational routine: A systematic review of the literature. Am. J. Prev. Med. 2011, 40, 76-93. [CrossRef] [PubMed]

11. Calfas, K.J.; Long, B.J.; Sallis, J.F.; Wooten, W.J.; Pratt, M.; Patrick, K. A controlled trial of physician counseling to promote the adoption of physical activity. Prev. Med. 1996, 25, 225-233. [CrossRef] [PubMed]

12. DeNelsky, G.Y.; McKee, M.G. Prediction of job performance from assessment reports: Use of a modified Q-sort technique to expand predictor and criterion variance. J. Appl. Psychol. 1969, 53, 439-445. [CrossRef]

13. Falkenberg, L.E. Employee fitness programs: Their impact on the employee and the organization. Acad. Manag. Rev. 1987, 12, 511-522. [CrossRef]

14. Mills, P.R.; Kessler, R.C.; Cooper, J.; Sullivan, S. Impact of a health promotion program on employee health risks and work productivity. Am. J. Health Promot. 2007, 22, 45-53. [CrossRef] [PubMed]

15. Mokaya, S.O.; Gitari, J.W. Effects of workplace recreation on employee performance the case of Kenya Utalii. Coll. Int. J. Humanit. Soc. Sci. 2012, 2, 176-183.

16. Pronk, N.P.; Martinson, B.; Kessler, R.C.; Beck, A.L.; Simon, G.E.; Wang, P. The association between work performance and physical activity, cardiorespiratory fitness and obesity. J. Occup. Environ. Med. 2004, 46, 19-25. [CrossRef] [PubMed]

17. Wattles, M.G.; Harris, C. The Relationship between Fitness Levels and Employee's Perceived Productivity, Job Satisfaction and Absenteeism. Master's Thesis, Boise State University, Boise, ID, USA, 1997.

18. Der-Karabetian, A.; Gebharbp, N. Effect of physical fitness program in the workplace. J. Bus. Psychol. 1986, 1, 51-58. [CrossRef]

19. Kumar, S.; McCalla, M.; Lybeck, E. Operational impact of employee wellness programs: A business case study. Int. J. Product. Perform. Manag. 2009, 58, 581-597. [CrossRef]

20. Neck, C.P.; Cooper, K.H. The fit executive: Exercise and diet guidelines for enhancing performance. Acad. Manag. Exec. 2000, 14, 72-83. [CrossRef]

21. Pelletier, B.; Boles, M.; Lynch, W. The relationship between health risks and work productivity. J. Occup. Environ. Med. 2004, 46, 737-745. [CrossRef]

22. Shephard, R.J. A critical analysis of work-site fitness programs and their postulated economic benefits. Med. Sci. Sports Exerc. 1992, 24, 354-370. [CrossRef] [PubMed]

23. Shephard, R.J. Do work-site exercise and health programs work? Phys. Sportsmed. 1999, 27, 48-72. [CrossRef] [PubMed]

24. Frew, D.R.; Bruning, N.S. The effect of employees' participation in an exercise program on increasing job satisfaction and productivity. Phys. Sports Med. 1988, 27, 48-72.

25. Conn, V.S.; Hafdahl, A.R.; Cooper, P.S.; Brown, L.M.; Lusk, S.L. Meta-analysis of workplace physical activity interventions. Am. J. Prev. Med. 2009, 37, 330-339. [CrossRef] [PubMed]

26. Donaghy, M.E. Exercise can seriously improve your mental health: Fact or fiction? Adv. Physiother. 2007, 9, 76-88. [CrossRef]

27. Lupinacci, N.S.; Rikli, R.E.; Jones, C.J.; Ross, D. Age and physical activity effects on reaction time and digit symbol substitution performance in cognitively active adults. Res. Q. Exerc. Sport 1993, 64, 144-150. [CrossRef] [PubMed]

28. Searle, A.; Calnan, M.; Lewis, G.; Campbell, J.; Taylor, A.; Turner, K. Patients' views of physical activity as treatment for depression: A qualitative study. Br. J. Gen. Pract. 2011, 61, e149-e156. [CrossRef] [PubMed]

29. Ganster, D.C.; Schaubroeck, J. Work stress and employee health. J. Manag. 1991, 17, 235-271. [CrossRef]

30. Greene, J. Employee wellness proves its worth. Hosp. Health Netw. 2011, 85, 41-44. [PubMed]

31. Jacobson, B.H.; Aldana, S.G. Relationship between frequency of aerobic activity and illness-related absenteeism in a large employee sample. J. Occup. Environ. Med. 2001, 43, 1019-1025. [CrossRef] [PubMed] 
32. Kerr, J.H.; Vos, M.C. Employee fitness programmes, absenteeism and general well-being. Work Stress 1993, 7 , 179-190. [CrossRef]

33. Van den Heuvel, S.G.; Boshuizen, H.C.; Hildebrandt, V.H.; Blatter, B.M.; Ariëns, G.A.; Bongers, P.M. Effect of sporting activity on absenteeism in a working population. Br. J. Sports Med. 2005, 39, e15. [CrossRef] [PubMed]

34. Biddle, S. Exercise and psychosocial health. Res. Q. Exerc. Sport 1995, 66, 292-297. [CrossRef] [PubMed]

35. Goyal, P.; Rahman, Z.; Kazmi, A.A. Corporate sustainability performance and firm performance research. Manag. Decis. 2013, 51, 361-379. [CrossRef]

36. Lourenco, I.C.; Branco, M.C.; Curto, J.D.; Eugenio, T. How does the market value corporate sustainability performance? J. Bus. Ethics 2012, 108, 417-428. [CrossRef]

37. Eccles, R.G.; Ioannou, I.; Serafeim, G. The impact of corporate sustainability on organizational processes and performance. Manag. Sci. 2014, 60, 2835-2857. [CrossRef]

38. Lee, S.; Ha-Brookshire, J. Ethical climate and job attitude in fashion retail employees' turnover intention, and perceived organizational sustainability performance: A cross-sectional study. Sustainability 2017, $9,465$. [CrossRef]

39. Chen, C.; Delmas, M. Measuring corporate social performance: An efficiency perspective. Prod. Oper. Manag. 2011, 20, 789-804. [CrossRef]

40. Bhattacharyya, A.; Cummings, L. Measuring corporate environmental performance-Stakeholder engagement evaluation. Bus. Strategy Environ. 2015, 24, 309-325. [CrossRef]

41. Parks, K.M.; Steelman, L.A. Organizational wellness programs: A meta-analysis. J. Occup. Health Psychol. 2008, 13, 58-68. [CrossRef] [PubMed]

42. Rhoades, L.; Eisenberger, R. Perceived organizational support: A review of the literature. J. Appl. Psychol. 2002, 87, 698-714. [CrossRef] [PubMed]

43. Byrne, Z.S.; Hochwarter, W.A. Perceived organizational support and performance. J. Manag. Psychol. 2008, 23, 54-72. [CrossRef]

44. Rae, K.; Sand, J.; Gadenne, D. The association between organisational commitment and corporate social responsibility-environmental performance within an integrated sustainability balanced scorecard framework. Issues Soc. Environ. Account. 2015, 9, 32-50. [CrossRef]

45. Susskind, A.M.; Borchgrevink, C.P.; Kacmar, K.M.; Brymer, R.A. Customer service employees' behavioral intentions and attitudes: An examination of construct validity and a path model. Int. J. Hosp. Manag. 2000, 19, 53-77. [CrossRef]

46. Vroom, V.H. Ego-Involvement Job Satisfaction and Job Performance. Pers. Psychol. 1964, 15, $159-177$. [CrossRef]

47. Price, J.L. Handbook of Organizational Measurement. Int. J. Manpow. 1997, 18, 305-558. [CrossRef]

48. Porter, L.W.; Lawler, E.E. Managerial Attitudes and Performance; Irwin: Homewood, IL, USA, 1968.

49. Robbins, S.P. Organizational Behavior: Concepts, Controversies, and Applications; Prentice Hall: Toronto, ON, Canada, 2001.

50. Burke, R.J. Hospital restructuring, workload, and nursing staff satisfaction and work experiences. Health Care Manag. 2003, 22, 99. [CrossRef]

51. Harris, R.B.; Harris, K.J.; Harvey, P. A test of competing models of the relationships among perceptions of organizational politics, perceived organizational support, and individual outcomes. J. Soc. Psychol. 2007, 147, 631-655. [CrossRef] [PubMed]

52. Okpara, J.O.; Squillace, M.; Erondu, E.A. Gender differences and job satisfaction: A study of university teachers in the United States. Women Manag. Rev. 2013, 20, 177-190. [CrossRef]

53. Brooks, R. Why loyal employees and customers improve the bottom line. J. Qual. Particip. 2000, 23, 40-44.

54. Choo, S.; Bowley, C. Using training and development to affect job satisfaction within franchising. J. Small Bus. Enterp. Dev. 2007, 14, 339-352. [CrossRef]

55. Porter, L.; Steers, R.; Mowday, R.; Boulian, P. Organizational commitment, job satisfaction and turnover among psychiatric technicians. J. Appl. Psychol. 1974, 59, 603-609. [CrossRef]

56. Bartlett, K.R. The relationship between training and organizational commitment: A study in the health care field. Hum. Resour. Dev. Quart. 2001, 12, 335-351. [CrossRef]

57. Meyer, J.P.; Allen, N.J. Commitment in the Workplace: Theory, Research, and Application; SAGE: Thousand Oaks, CA, USA, 1997. 
58. Meyer, J.P.; Allen, N.J. Testing the "side-bet theory" of organizational commitment: Some methodological considerations. J. Appl. Psychol. 1984, 69, 372-378. [CrossRef]

59. Allen, N.J.; Meyer, J.P. The measurement and antecedents of affective, continuance and normative commitment to the organization. J. Occup. Organ. Psychol. 1990, 63, 1-18. [CrossRef]

60. Aydogdu, S.; Asikgil, B. An empirical study of the relationship among job satisfaction, organizational commitment and turnover intention. Int. Rev. Manag. Mark. 2011, 1, 56-63.

61. Eisenberger, S.; Fasolo, P.; Davis-LaMastro, V. Perceived organizational support and employee diligence, commitment, and innovation. J. Appl. Psychol. 1990, 75, 51-59. [CrossRef]

62. Rhoades, L.; Eisenberger, R.; Armeli, S. Affective commitment to the organization: The contribution of perceived organizational support. J. Appl. Psychol. 2001, 86, 825-836. [CrossRef] [PubMed]

63. Rauch, A.; Wiklund, J.; Lumpkin, G.T.; Frese, M. Entrepreneurial orientation and business performance: An assessment of past research and suggestions for the future. Entrep. Theory Pract. 2009, 33, 761-787. [CrossRef]

64. Kearins, K.; Collins, E.; Tregidga, H. Beyond corporate environmental management to a consideration of nature in visionary small enterprise. Bus. Soc. 2010, 49, 512-547. [CrossRef]

65. Schaltegger, S.; Synnestvedt, T. The link between 'green' and economic success: Environmental management as the crucial trigger between environmental and economic performance. J. Environ. Manag. 2002, 65, 339-346.

66. Singh, M.P.; Chakraborty, A.; Roy, M. Entrepreneurial commitment, organizational sustainability and business performance of manufacturing MSMES: Evidence from India. Int. J. Appl. Bus. Econ. Res. 2016, 14, 4615-4631.

67. Chou, S.Y.; Pearson, J.M. Organizational citizenship behavior in IT professionals: An expectancy theory approach. Manag. Res. Rev. 2012, 35, 1170-1186. [CrossRef]

68. Lamm, E.; Tosti-Kharas, J.; King, C.E. Empowering employee sustainability: Perceived organizational support toward the environment. J. Bus. Ethics 2015, 128, 207-220. [CrossRef]

69. Cammann, C.; Fichman, M.; Jenkins, D.; Klesh, J. Assessing the attitudes and perceptions of organizational members. In Assessing Organizational Change: A Guide to Methods, Measures and Practices; Seashore, S., Lawler, E., Mirvis, P., Cammann, C., Eds.; Wiley: New York, NY, USA, 1983; p. 84.

70. Pan, S.L.; Wu, H.C.; Morrison, A.M.; Huang, M.T.; Huang, W.S.; Rosen, M.A. The relationships among leisure involvement, organizational commitment and well-being: Viewpoints from sport fans in Asia. Sustainability 2018, 10, 740. [CrossRef]

71. Bagozzi, R.P.; Yi, Y. On the evaluation of structural equation models. J. Acad. Mark. Sci. 1988, 16, 74-94. [CrossRef]

72. Bentler, P.M.; Bonett, D.G. Significance tests and goodness of fit in the analysis of covariance structures. Psychol. Bull. 1980, 88, 588-606. [CrossRef]

73. Angelia, D.; Suryaningsih, R. The effect of environmental performance and corporate social responsibility disclosure towards financial performance (case study to manufacture, infrastructure, and service companies that listed at Indonesia stock exchange. Procedia Soc. Behav. Sci. 2015, 211, 348-355. [CrossRef]

74. Andewi, R.; Milind, S.; Suneeta, S. The Effect of GHG Emission, Environmental Performance, and Social Performance on Financial Performance of Listed Manufacturing Firms in Indonesia. Procedia Soc. Behav. Sci. 2015, 211, 461-470.

75. Meyer, J.P.; Stanley, D.J.; Herscovitch, L.; Topolnytsky, L. Affective, continuance, and normative commitment to the organization: A meta-analysis of antecedents, correlates, and consequences. J. Vocat. Bus. 2002, 61, 20-52. [CrossRef]

76. Harness, D.; Ranaweera, C.; Karjaluoto, H.; Jayawardhena, C. The role of negative and positive forms of power in supporting CSR alignment and commitment between large firms and SMEs. Ind. Mark. Manag. 2018. [CrossRef]

77. Withey, M.; Cooper, W. Predicting exit, voice, loyalty, and neglect. Adm. Sci. Quart. 1989, 34, 521-539. [CrossRef]

78. Shanock, L.R.; Eisenberger, S. When supervisors feel supported: Relationships with subordinates' perceived supervisor support, perceived organizational support, and performance. J. Appl. Psychol. 2006, 91, 689-695. [CrossRef] [PubMed] 
79. Fasolo, P. Procedural justice and perceived organizational support: Hypothesized effects on job performance. In Organizational Politics, Justice, and Support: Managing the Social Climate of the Workplace; Cropanzano, R.S., Kacmar, K.M., Eds.; Quorum: Westport, CT, USA, 1995; pp. 185-195.

80. Rocha, C.M.; Chelladurai, P. The relationship between organizational support and Performance of College: A Mediational Model. Eur. Sport Manag. Quart. 2011, 11, 301-319. [CrossRef]

81. Pyle, R.L. Performance measures for a corporate fitness program. Hum. Resour. Manag. 1979, 18, $26-30$. [CrossRef]

82. Clutterbuck, D. Executive fitness aids corporate health. Int. Manag. 1980, 35, 18-20.

83. Neves, P.; Eisenberger, R. Management communication and employee performance: The contribution of perceived organizational support. Hum. Perform. 2012, 25, 452-464. [CrossRef]

2018 by the authors. Licensee MDPI, Basel, Switzerland. This article is an open access article distributed under the terms and conditions of the Creative Commons Attribution (CC BY) license (http:/ / creativecommons.org/licenses/by/4.0/). 